Research Paper

\title{
Colorectal cancer at high risk of peritoneal metastases: long term outcomes of a pilot study on adjuvant laparoscopic HIPEC and future perspectives
}

\author{
Charlotte E.L. Klaver ${ }^{1}$, Roos Stam ${ }^{1}$, Didi A.M. Sloothaak ${ }^{1}$, Johannes Crezee ${ }^{2}$, Willem \\ A. Bemelman ${ }^{1}$, Cornelis J.A. Punt ${ }^{3}$ and Pieter J. Tanis ${ }^{1}$ \\ ${ }^{1}$ Department of Surgery, Academic Medical Center, Meibergdreef 9, 1105 AZ Amsterdam, The Netherlands \\ ${ }^{2}$ Department of Radiation Oncology, Academic Medical Center, Meibergdreef 9, 1105 AZ Amsterdam, The Netherlands \\ ${ }^{3}$ Department of Medical Oncology, Academic Medical Center, Meibergdreef 9, 1105 AZ Amsterdam, The Netherlands \\ Correspondence to: Pieter J. Tanis, email: p.j.tanis@amc.uva.nl
}

Keywords: colorectal cancer, peritoneal metastases, adjuvant HIPEC

Received: September 26, $2016 \quad$ Accepted: March 10,2017 Published: April 17, 2017

Copyright: Klaver et al. This is an open-access article distributed under the terms of the Creative Commons Attribution License 3.0 (CC BY 3.0), which permits unrestricted use, distribution, and reproduction in any medium, provided the original author and source are credited.

\section{ABSTRACT}

Objective: Early detection of peritoneal metastases (PM) of colorectal cancer (CRC) is difficult and treatment options at a clinically overt stage are limited. Potentially, adjuvant laparoscopic hyperthermic intraperitoneal chemotherapy (HIPEC) is of value. The aim of this study was to present long term oncological outcomes of a pilot study on adjuvant HIPEC to reduce development of PMCRC, with systematic review of literature.

Methods: Long term oncological outcomes of ten patients who underwent laparoscopic HIPEC within eight weeks after resection of primary CRC in the pilot study were retrospectively collected. A systematic search of literature was performed on studies describing the use of HIPEC in patients with CRC at high risk of developing PM.

Results: The median follow-up was 54 months (range 49-63). All patients were alive at the last follow-up moment and none of them had developed PM. Two patients had developed pulmonary metastases. Systematic review revealed five small cohort studies, including two matched comparisons. Peritoneal recurrences were found in $\mathbf{0 \%}$ to $\mathbf{9 \%}$ after adjuvant HIPEC, which was $\mathbf{2 8 \%}$ and $\mathbf{4 3} \%$ in the two control groups, respectively. Disease free and overall survival were significantly higher in favour of HIPEC.

Conclusion: Long term follow-up of ten patients included in a pilot study on adjuvant HIPEC revealed no peritoneal recurrences. This result is in line with other published pilot studies, a promising observation. However, the outcomes of the Dutch randomized COLOPEC trial and similar trials worldwide should be awaited for definitive conclusions on the effectiveness of adjuvant HIPEC.

\section{INTRODUCTION}

The peritoneum is the third most common site of recurrence in colorectal cancer (CRC), and the incidence of peritoneal metastases (PMCRC) might even be higher than reported. This is because of the restricted sensitivity of imaging modalities for the small flat peritoneal lesions, which complicates the clinical diagnosis of PMCRC. The disease is often detected at a late symptomatic stage. Then, prognosis is poor and PMCRC seems to be relatively resistant to systemic therapy [1]-[5]. Only patients in good clinical condition with a limited extent of PMCRC are eligible for a curative intent treatment [6]. This consists of cytoreductive surgery with hyperthermic intraperitoneal chemotherapy (CRS/HIPEC), a procedure with a substantial risk of morbidity [7]-[9].

The difficulties with early detection of the disease, together with the restrictions of curative intent treatment options at a clinical overt stage, necessitate development of new therapeutic approaches for patients at high risk 
of PMCRC. Currently, prophylactic or adjuvant HIPEC and second look surgery, both aiming at treating PMCRC in an earlier (subclinical) phase, are under investigation [10]. Selection of high risk patients eligible for these approaches is based on risk factors identified in literature, including T4 stage [11]-[16], bowel perforation [16], [17], mucinous subtype [16], [18], and positive cytology of peritoneal lavage [16], [19]. Another relevant subgroup is the group of patients with already proven limited PMCRC that was resected together with the primary tumour or resected ovarian metastases. These high risk patients might be considered eligible for a second look strategy. Alternatively, prophylactic HIPEC at time of diagnosis might be considered [17].

In preparation of a randomized trial determining the effectiveness of adjuvant HIPEC, a single centre pilot study of ten high risk patients was performed in 2011 in order to determine the feasibility of adjuvant laparoscopic HIPEC in a short stay setting [20]. Feasibility criteria included: postoperative hospital stay of three days or shorter in at least six patients, a maximum of one conversion and a maximum of one re-admission within 30 days. These predefined feasibility criteria were fulfilled and adjuvant laparoscopic HIPEC was considered feasible. In the present analyses long term oncological outcomes of this pilot study are presented. In addition, an update of our systematic review of literature on adjuvant HIPEC [21] and an overview of other experimental strategies aiming at treating PMCRC in an earlier phase is given.

\section{RESULTS}

\section{Update of the pilot study on adjuvant staged laparoscopic HIPEC}

Baseline patient and disease characteristics are shown in Table 1. Nine patients were diagnosed with a T4 tumour, of which four were classified as T4b (tumour extension into adjacent organs/structures). At time of diagnosis nodal metastases were present in six patients, three patients already presented with omental metastases and one patient had simultaneous ovarian metastasis. The omental and ovarian metastases were resected simultaneous with the primary tumour. The type of primary tumour resection and additional resections for $\mathrm{T} 4$ stage or limited peritoneal metastases for each of the ten patients are displayed in Table 2. A primary anastomosis was made in all ten patients, with diverting ileostomy in one of these patients. The primary tumour resection was radical (R0) in seven out of ten patients. The median time interval between resection of the primary tumour and adjuvant laparoscopic HIPEC was six weeks.

All patients started with adjuvant systemic treatment, except for one patient who refused. Median interval between resection of the primary tumour and adjuvant systemic chemotherapy was ten weeks, with all patients starting within 12 weeks postoperatively. Six patients completed their adjuvant chemotherapy (four patients received CAPOX, two FOLFOX). In two patients, chemotherapy (CAPOX) was switched to capecitabin monotherapy after four and five cycles respectively, due to neurotoxicity and/or trombopenia. One patient completed only six cycles of FOLFOX, for unknown reasons. One patient experienced ascites after five cycles of systemic chemotherapy. Cytology did not reveal malignancy and ascites spontaneously disappeared. No further events were reported during adjuvant systemic chemotherapy.

The median follow-up was 54 months (range 4963). All patients were alive at the last follow-up moment and none of them has developed PMCRC (Figure 1). Two patients had disease recurrence, consisting of pulmonary metastases in both patients (Table 3), after 26 and 38 months respectively. Both patients underwent a microscopic irradical (R1) resection of the primary tumour (pT3N0 and pT4N1 respectively) and both had already intraperitoneal metastatic disease at time of resection of the primary tumour (an omental and an ovarian metastasis, respectively). One patient did not receive treatment for the pulmonary metastases but was carefully monitored and disease was stable at last follow-up. The other patient underwent a resection of the metastasis in the left upper lobe with curative intent and was disease free at last follow-up.

\section{Update of the systematic review of literature}

Repeating the literature search with restricted inclusion criteria revealed a total of five cohort studies on adjuvant HIPEC. One additional study of interest was published since our search in September 2013 [22], and the results of one study [23] were updated with longterm survival [24]. The inclusion criteria and treatment schedules are summarized in Table 4. Reported peritoneal recurrence rates until end of follow-up ranged from $0 \%$ to $9 \%$. Two studies included a matched comparison with a control group of patients who underwent resection of the primary tumour followed by only adjuvant systemic therapy. In both studies, peritoneal recurrence rate, disease free survival, and overall survival were significantly different between the experimental and control group in favour of the intervention consisting of prophylactic target organ resection and simultaneous HIPEC at the time of primary tumour resection.

\section{DISCUSSION}

The present update of the small feasibility study of adjuvant laparoscopic HIPEC in preventing the development of PMCRC in high risk patients shows promising results. In none of the ten patients, peritoneal recurrence was detected after a median follow-up of 54 months, while in these high risk patients peritoneal 
Table 1: Patient and disease characteristics

\begin{tabular}{|c|c|}
\hline & $\mathbf{N}=\mathbf{1 0}$ \\
\hline Male: female & $5: 5$ \\
\hline Age (median, years) [range] & 59 [39-65] \\
\hline \multicolumn{2}{|l|}{ ASA-score } \\
\hline 1 & 5 \\
\hline 2 & 5 \\
\hline \multicolumn{2}{|l|}{ pT } \\
\hline $\mathrm{T} 3$ & 1 \\
\hline $\mathrm{T} 4 \mathrm{a}$ & 5 \\
\hline $\mathrm{T} 4 \mathrm{~b} *$ & 4 \\
\hline \multicolumn{2}{|l|}{$\mathrm{pN}$} \\
\hline N0 & 4 \\
\hline $\mathrm{N} 1 / 2$ & 6 \\
\hline \multicolumn{2}{|l|}{$\mathrm{pM}$} \\
\hline M0 & 6 \\
\hline $\mathrm{M} 1 * *$ & 4 \\
\hline \multicolumn{2}{|l|}{ Risk factor(s) for peritoneal metastases } \\
\hline pT4 (only) & 3 \\
\hline Omental metastasis & 2 \\
\hline Omental metastasis and perforation & 1 \\
\hline Ovarian metastasis & 1 \\
\hline Obstruction / perforation & 2 \\
\hline Positive lavage & 1 \\
\hline \multicolumn{2}{|l|}{ Location of primary tumour } \\
\hline Rectosigmoid & 4 \\
\hline Transverse colon & 2 \\
\hline Ascending colon & 3 \\
\hline Caecum & 1 \\
\hline
\end{tabular}

$\mathrm{ASA}=$ American Society of Anesthesiologist; pTN = pathological TN. *In case of pathologic confirmation of tumour extension into adjacent organs/tissue, the tumour was classified as T4b. **M1: refers to resected solitary intraperitoneal metastases (ovarian / omental).

recurrence rates between $14 \%$ and $58 \%$ are described in the literature [11], [19], [25]-[27]. Two patients developed distant metastases, of whom one underwent an intentionally curative resection. Moreover, all ten patients are still alive. Although the sample size is too small to draw conclusions, these results are in line with the encouraging results of five other studies investigating the role of adjuvant HIPEC in high risk CRC patients, as identified by systemic review of the literature (Table 4).

The interest in adjuvant HIPEC for high risk CRC is a revival of a treatment strategy that originates from the
1980 's. In the era of 5-FU as the only available cytotoxic agent for CRC, adjuvant intraperitoneal chemotherapy has been investigated, using administration of 5-FU through a peritoneal catheter in the immediate postoperative period or as prolonged treatment up to 12 months [28]-[31]. The update of our previously published systematic review reveals that the currently available evidence on adjuvant HIPEC is still restricted and consists of five small cohort studies. Follow up was relatively short in the three noncomparative series [32]-[34]. In the two other studies [7], [24] simultaneous HIPEC with so-called 'target organ 


\begin{tabular}{|c|c|c|c|c|c|c|}
\hline & $\begin{array}{l}\text { Primary } \\
\text { resection }\end{array}$ & $\begin{array}{l}\text { Additional } \\
\text { resections* }\end{array}$ & $\begin{array}{l}\text { Radicality of } \\
\text { resection }\end{array}$ & $\begin{array}{c}\text { Interval } \\
\text { between } \\
\text { primary } \\
\text { resection and } \\
\text { HIPEC (weeks) }\end{array}$ & $\begin{array}{c}\text { Interval } \\
\text { between } \\
\text { primary } \\
\text { resection and } \\
\text { adjuvant } \\
\text { chemotherapy } \\
\text { (weeks) }\end{array}$ & $\begin{array}{c}\text { Adjuvant } \\
\text { chemotherapy } \\
* *\end{array}$ \\
\hline 1 & $\begin{array}{c}\text { Right } \\
\text { hemicolectomy }\end{array}$ & $\begin{array}{l}\text { Partial small } \\
\text { bowel, } \\
\text { abdominal wall }\end{array}$ & R1 & 6 & 10 & $\begin{array}{c}4 \text { x CAPOX } \\
4 \mathrm{x} \text { capecitabin } \\
\text { monotherapy }\end{array}$ \\
\hline 2 & Proctocolectomy & $\begin{array}{c}\text { Omental } \\
\text { metastasis }\end{array}$ & R0 & 4 & 10 & $12 \times$ FOLFOX \\
\hline 3 & $\begin{array}{l}\text { Subtotal } \\
\text { colectomy }\end{array}$ & Omentum & R0 & 3 & 7 & $\begin{array}{l}5 \times \text { CAPOX, } \\
3 x \text { capecitabin } \\
\text { monotherapy }\end{array}$ \\
\hline 4 & $\begin{array}{c}\text { Right } \\
\text { hemicoloectomy }\end{array}$ & $\begin{array}{c}\text { Omental } \\
\text { metastasis, psoas } \\
\text { muscle }\end{array}$ & R1 & 7 & 10 & $12 \times$ FOLFOX \\
\hline 5 & $\begin{array}{l}\text { Low anterior } \\
\text { resection }\end{array}$ & $\begin{array}{l}\text { Hysterectomy, } \\
\text { bilateral } \\
\text { sapingectomy, } \\
\text { ileocecal } \\
\text { resection, } \\
\text { omentectomy }\end{array}$ & R0 & 3 & 10 & 8x CAPOX \\
\hline 6 & $\begin{array}{l}\text { Subtotal } \\
\text { colectomy }\end{array}$ & No & R0 & 6 & 8 & $8 \times$ CAPOX \\
\hline 7 & $\begin{array}{l}\text { Low anterior } \\
\text { resection }\end{array}$ & $\begin{array}{l}\text { Partial small } \\
\text { bowel, } \\
\text { abdominal wall }\end{array}$ & R0 & 6 & 8 & 8x CAPOX \\
\hline 8 & $\begin{array}{c}\text { Right } \\
\text { hemicolectomy }\end{array}$ & $\begin{array}{l}\text { Omental } \\
\text { metastasis }\end{array}$ & R0 & 9 & NA & $\begin{array}{c}\text { Refused adjuvant } \\
\text { systemic } \\
\text { treatment }\end{array}$ \\
\hline 9 & $\begin{array}{c}\text { Right } \\
\text { hemicolectomy }\end{array}$ & No & R0 & 6 & 12 & 6x FOLFOX \\
\hline \multirow[t]{2}{*}{10} & $\begin{array}{l}\text { Low anterior } \\
\text { resection }\end{array}$ & $\begin{array}{c}\text { Ovarian } \\
\text { metastasis }\end{array}$ & $\mathrm{R} 1$ & 4 & 8 & 8x CAPOX \\
\hline & & & & $\begin{array}{c}\text { Median (range): } \\
6(3-9)\end{array}$ & $\begin{array}{c}\text { Median (range): } \\
10(7-12)\end{array}$ & \\
\hline
\end{tabular}

CAPOX: combined schedule of capecitabin and oxaliplatin (standard 8 cycles); HIPEC = hyperthermic intraperitoneal chemotherapy; FOLFOX: combined schedule of 5-fluoruracil and oxaliplatin (standard 12 cycles); NA: not applicable; R0: microscopic complete tumour resection with all margins $>1 \mathrm{~mm}$; R1: microscopic margin involvement or margin $\leq 1 \mathrm{~mm}$. *Additional resections, either of adjacent organs /structures because of suspected tumour ingrowth, or additional resections of metastases. ** Number of cycles and chemotherapeutic scheme.

resection' was compared to a matched control group and intermediate follow-up results have been published. A significantly lower incidence of peritoneal metastases in the experimental group was observed (4\% vs. $28 \%$ and $9 \%$ vs. $43 \%$, respectively), together with a significantly better survival (median OS: 60 vs. 52 months and 5yOS: 81\% vs. $70 \%$, respectively).

The initial results of our pilot study and the literature review supported the conduction of a randomized trial at that time, to determine the effectiveness of adjuvant 
Table 3: Long term oncological outcome

\begin{tabular}{lc}
\hline & $\mathbf{N = 1 0}$ \\
\hline Median follow-up (range) & $54(49-63)$ \\
Alive at end of follow-up & $10 / 10$ \\
Local recurrence & $0 / 10$ \\
Peritoneal metastases & $0 / 10$ \\
Liver metastasis & $0 / 10$ \\
Pulmonary metastasis & $2 / 10$ \\
Other metastasis & $0 / 10$ \\
\hline
\end{tabular}

HIPEC in preventing the development of PMCRC in high risk patients. Currently the COLOPEC multicentre randomized trial (NCT02231086) is recruiting. Included patients with T4 or perforated colon cancer are randomized between simultaneous or staged (5-8 weeks) open or laparoscopic HIPEC followed by adjuvant systemic chemotherapy, and a control arm of systemic chemotherapy alone [10]. Patient accrual is ahead of schedule and is expected to be finalized in the beginning of
2017. The primary outcome is peritoneal recurrence free survival after 18 months, which will be determined using laparoscopy in both study arms. Morbidity of adjuvant HIPEC is an important secondary outcome, considering the fact that the treatment is applied in a preventive setting. This means that the majority of patients undergo additional treatment without benefit, but with potential harm. Furthermore patients will be followed for a period of five years for (secondary) survival outcomes.

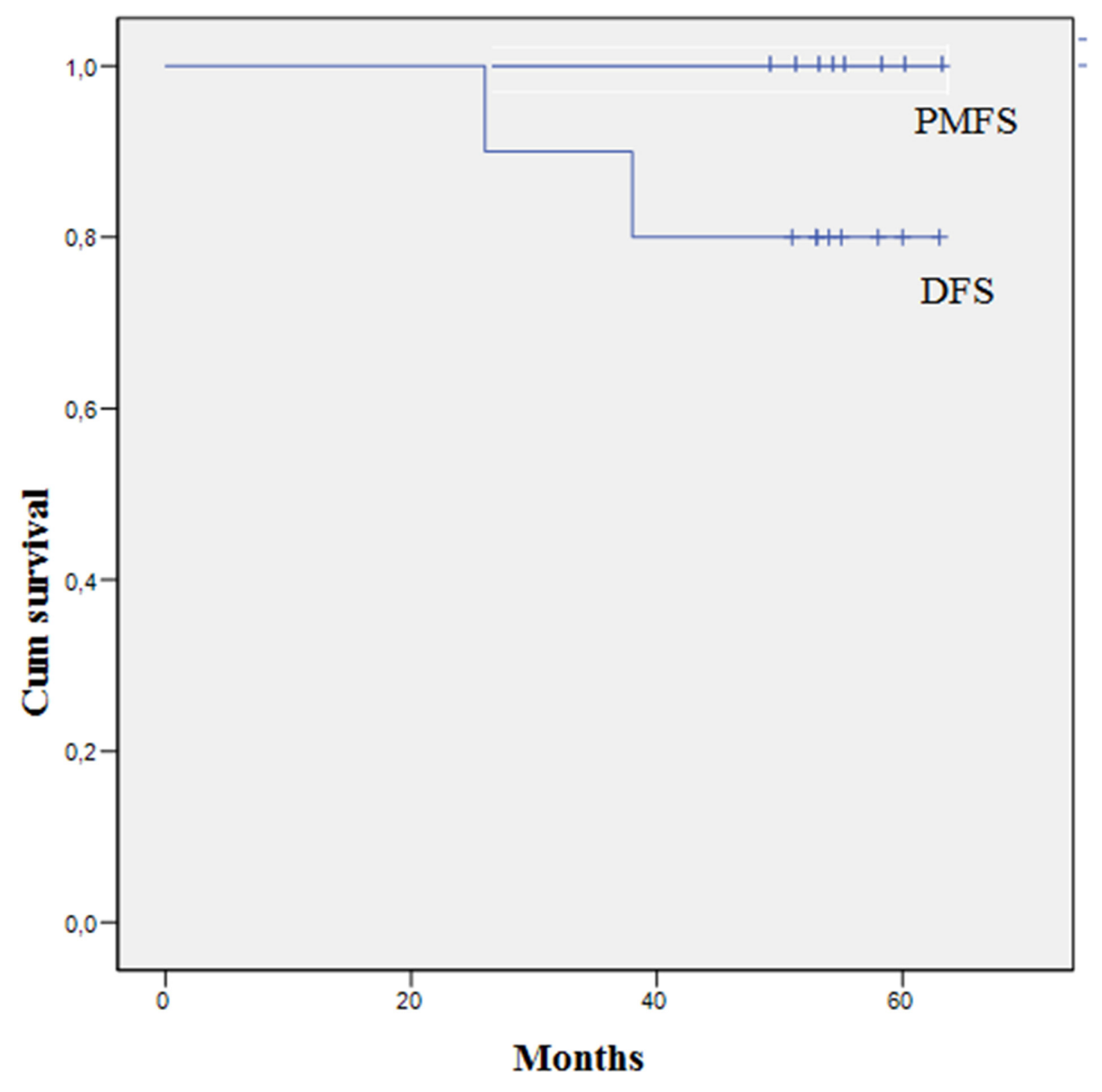

Figure 1: Disease free survival after adjuvant HIPEC. PMFS: peritoneal metastases free survival. DFS: Disease free survival. 
Table 4: Results of updated systematic review on adjuvant HIPEC in colorectal cancer patients at high risk of developing peritoneal metastases

\begin{tabular}{|c|c|c|c|c|c|}
\hline $\begin{array}{l}\text { author, } \\
\text { year, } \\
\text { design }\end{array}$ & inclusion criteria & $\mathbf{n}$ & $\begin{array}{c}\text { HIPEC strategy + } \\
\text { adjuvant systemic } \\
\text { therapy }\end{array}$ & $\begin{array}{l}\text { Overall / disease } \\
\text { free survival }\end{array}$ & Peritoneal recurrence \\
\hline $\begin{array}{l}\text { Chouillard } \\
\text { 2009, single } \\
\text { centre cohort } \\
{[32]}\end{array}$ & $\begin{array}{c}\text { colorectal cancer } \\
\text {-T4, } \\
\text {-pN2, } \\
\text {-perforation, } \\
\text {-positive peritoneal } \\
\text { lavage, } \\
\text { - peritumoral } \\
\text { peritoneal nodules }\end{array}$ & 16 & $\begin{array}{c}\text { Laparoscopic HIPEC, } \\
\text { staged (median } \\
\text { 5weeks, rang }(0-8)) \\
\mathrm{MMC} 80 \mathrm{mg} / \mathrm{m} 2, \\
\mathrm{~T}=42-44^{\circ} \mathrm{C} \mathrm{t}=35- \\
45 \mathrm{~min}\end{array}$ & $\begin{array}{l}\text { median FU } 15.5 \\
\text { months } \\
2 / 16 \text { died } \\
3 / 14 \text { alive with } \\
\text { metastasis }\end{array}$ & $\begin{array}{l}0 \% \text { (median FU } 15.5 \\
\text { months, range } 8-29 \text { ) }\end{array}$ \\
\hline $\begin{array}{l}\text { Lygidakis, } \\
\text { 2010, single } \\
\text { centre cohort } \\
{[34]}\end{array}$ & $\begin{array}{c}\text { rectal cancer } \\
\mathrm{N}+\text {, neurovascular } \\
\text { involvement }\end{array}$ & 87 & $\begin{array}{l}\text { Laparoscopic HIPEC, } \\
\text { three procedures ( } 22 \\
\text { days post-op, } 25 \text { days } \\
\text { postop, } 2 \text { years postop) } \\
\text { ip } 5 \mathrm{FU}, \mathrm{Ox}, \mathrm{LV} \text {, Ir; } \\
\mathrm{T}=43 \mathrm{C}^{\circ} \text {; t=60min }\end{array}$ & 1 -year OS 100\% & $\begin{array}{l}5 \% \text { ( } 2 \text { of } 40 \text { patients who } \\
\text { completed } 2 \text { years of follow- } \\
\text { up and underwent the third } \\
\text { laparoscopic HIPEC) }\end{array}$ \\
\hline & & & $\begin{array}{c}(+4 \text { cycles iv } 5 \mathrm{FU}, \mathrm{Ox} \\
\mathrm{LV}, \mathrm{Ir})\end{array}$ & & \\
\hline $\begin{array}{l}\text { Tentes, } \\
2011, \text { single } \\
\text { centre cohort } \\
{[33]}\end{array}$ & $\begin{array}{l}\text { colorectal cancer } \\
\text { T3/4 }\end{array}$ & 40 & $\begin{array}{c}\text { Open, simultaneous } \\
\text { with tumour resection, } \\
\mathrm{MMC} 15 \mathrm{mg} / \mathrm{m} 2 \mathrm{~T}= \\
42.5-43^{\circ} \mathrm{C} \mathrm{t}=90 \mathrm{~min} \\
\text { or } \mathrm{Ox} 130 \mathrm{mg} / \mathrm{m} 2 \mathrm{~T}= \\
42.5-43^{\circ} \mathrm{C} \mathrm{t}=60 \mathrm{~min} \\
(+6 \text { cycles iv } 5 \mathrm{FU} / \mathrm{LV} \\
\text { in stage } \mathrm{III} / \mathrm{IV})\end{array}$ & $\begin{array}{c}\text { actuarial 3-year OS } \\
100 \%\end{array}$ & 0\% (median FU 17 months) \\
\hline \multirow[t]{3}{*}{$\begin{array}{l}\text { Sammartino, } \\
2012,2014 \\
\text { matched } \\
\text { comparison } \\
\text { with control } \\
\text { group } \\
{[23],[24]}\end{array}$} & $\begin{array}{l}\text { signet ring cell or } \\
\text { mucinous colon } \\
\text { cancer } \\
\text { T3/4NxM0 }\end{array}$ & 25 & $\begin{array}{l}\text { Closed, simultaneous } \\
\text { with tumour resection, } \\
\text { prophylactic target } \\
\text { organ resection } \\
\text { ( appendectomy, } \\
\text { omentectomy, resection } \\
\text { of the round hepatic } \\
\text { ligament and bilateral } \\
\text { ovariectomy) Ox } \\
460 \mathrm{mg} / \mathrm{m} 2 \mathrm{~T}=43^{\circ} \mathrm{C} \\
\mathrm{t}=30 \mathrm{~min},+\mathrm{iv} 5 \mathrm{FU}+ \\
\mathrm{LV} \\
\text { (iv } 5 \mathrm{FU} / \mathrm{Ox}(\mathrm{n}=13))\end{array}$ & $\begin{array}{l}\text { median DFS: } 36.8 \\
\text { months } \\
\text { median OS: } 59.5 \\
\text { months }\end{array}$ & $4 \%$ (FU >48 months) \\
\hline & & 50 & $(\mathrm{iv} 5 \mathrm{FU} / \mathrm{Ox}(\mathrm{n}=23))$ & $\begin{array}{l}\text { median DFS: } 21.9 \\
\text { months } \\
\text { median OS: } 52 \\
\text { months }\end{array}$ & $28 \%$ (FU $>48$ months $)$ \\
\hline & & & & $\begin{array}{l}p \text {-value }<0.05 \\
p \text {-value }<0.04\end{array}$ & $\begin{aligned} p \text {-value }< & 0.03 \\
& (\text { Continued })\end{aligned}$ \\
\hline
\end{tabular}




\begin{tabular}{|c|c|c|c|c|c|}
\hline $\begin{array}{l}\text { author, } \\
\text { year, } \\
\text { design }\end{array}$ & inclusion criteria & $\mathbf{n}$ & $\begin{array}{c}\text { HIPEC strategy + } \\
\text { adjuvant systemic } \\
\text { therapy }\end{array}$ & $\begin{array}{l}\text { Overall / disease } \\
\text { free survival }\end{array}$ & Peritoneal recurrence \\
\hline $\begin{array}{l}\text { Baratti } \\
2016 \\
\text { matched } \\
\text { comparison } \\
\text { with control } \\
\text { group } \\
\text { [22] }\end{array}$ & $\begin{array}{l}\text { Colorectal cancer, } \\
\text { - resected ovarian } \\
\text { metastases, } \\
\text { - minimal } \\
\text { synchronous } \\
\text { peritoneal disease } \\
(<1 \mathrm{~cm} \text { in the } \\
\text { omentum or close to } \\
\text { the primary tumour), } \\
\text { - T4a }(\mathrm{n}=8 \text { vs. } \mathrm{n}=18) \\
\text { - T4b }(\mathrm{n}=9 \text { vs. } \mathrm{n}=17)\end{array}$ & 44 & $\begin{array}{c}\text { Closed, simultaneous } \\
\text { with tumour resection, } \\
\text { prophylactic target } \\
\text { organ resection } \\
\text { (resection of the round } \\
\text { hepatic ligament and } \\
\text { lesser and greater } \\
\text { omentectomy) } \\
\text { Cisplatin } 25 \mathrm{mg} / \mathrm{m}^{2} / \mathrm{L} \\
+\mathrm{MMC} 3.3 \mathrm{mg} / \mathrm{m}^{2} / \mathrm{L} \\
\text { T=42.5 }{ }^{\circ} \mathrm{C}=60 \mathrm{~min} \\
\text { (iv 5FU/cap, FA, Ox } \\
\text { (n=14), iv 5FU/cap, } \\
\text { FA, Ox, Bev or Cet } \\
\text { (n=4), 5FU/cap, FA, Ir, } \\
\text { Bev or Cet (n=4)) } \\
\text { (iv 5FU/cap, FA, Ox } \\
\text { (n=29), iv 5FU/cap, } \\
\text { FA, Ox, Bev or Cet } \\
\text { (n=6), 5FU/cap, FA, Ir, } \\
\text { Bev or Cet (n=6)) }\end{array}$ & $\begin{array}{l}p \text {-value }=0.046 \\
p \text {-value }=0.008\end{array}$ & $\begin{array}{c}\text { 5y cumulative incidence } \\
42.5 \% \text { median FU } 34.5 \\
\text { months }\end{array}$ \\
\hline
\end{tabular}

Bev: bevacizumab; Cap: capecitabin; Cet: Cetuximab; DFS: disease free survival; FA: folinic acid; FU: follow-up; HIPEC: hyperthermic intraperitoneal chemotherapy; ip: intra peritoneal; Ir: irinotecan; iv: intravenous; LV: leucovorin; MMC: mitomycine-C; OS: overall survival; Ox: oxaliplatin; PFS: progression free survival; T: temperature of intraperitoneal infusion; t: duration of infusion; . $5 \mathrm{y}$ : 5 year; $5 \mathrm{FU}$ : fluorouracil.

Presently, several randomized trials investigating proactive protocols to prevent PMCRC are performed. In the French ProphyloCHIP trial (NCT01226394), the effectiveness of second look laparotomy six months postoperatively with 'in principle' HIPEC is investigated. High risk is defined as perforated tumours, (resected) local peritoneal nodules and ovarian metastases, although the latter two should actually be considered as already proven PMCRC. Patient accrual of this trial has been completed. A similar phase III trial started in October 2014 at the Zhejiang University, China, with second look laparotomy and HIPEC six months postoperatively, including also pT4 cancers in addition to the other three inclusion criteria of the French trial (NCT02179489). In Italy, a currently recruiting randomized trial investigates the role of second look surgery six months postoperatively in mucinous CRC (NCT01628211). Based on the results of the matched comparative study, Sammartino initiated the PROMENADE trial (NCT02974556), which will start in 2017. This trial randomizes between simultaneous adjuvant HIPEC (oxaliplatin) and target organ resection (omentectomy, bilateral adnexectomy in post-menopausal patients, appendectomy and hepatic round ligament resection), and a control group with only adjuvant systemic chemotherapy. At the $10^{\text {th }}$ international Congress on Peritoneal Surface Malignancies (November 2016, Washington), an almost similar Spanish multicentre study was presented, which already started accrual (NCT02614534). Inclusion in this trial is based on imaging with selection of only 'clear' cT4 stage colon cancer. In contrast to the PROMENADE trial, the Spanish trial also performs target organ resection, but without HIPEC, in the control arm.

The different approaches in the trials that are currently in conduct, reveal one of the key questions in adjuvant intraperitoneal treatment for patients at high risk of developing PMCRC; namely the timing of the intervention. Proposed strategies vary from HIPEC simultaneous with the resection of the primary tumour, to staged HIPEC (several weeks postoperatively), to second look surgery six to twelve months postoperatively with prophylactic HIPEC depending on intraoperative findings.

Patient inclusion essentially differs based on the chosen strategy of adjuvant HIPEC. Selection should 
be based on clinical criteria if HIPEC is performed simultaneous with primary resection. This includes pre-operative imaging, histological biopsies and intraoperative findings. However, based on our experience, it is difficult to adequately select patients based on clinical staging. A clear cT4 stage based on imaging or intraoperative findings quite frequently turns out to have a pathological T3 stage. Also, a patient with a T4 tumour may postoperatively be classified as having stage II disease with microsatellite instability, which is regarded as low risk disease. According to the current Dutch guidelines, this is even not an indication for adjuvant systemic chemotherapy. Contrarily, a small area of peritoneal penetration (pT4a) is only diagnosed after scrutinizing the resection specimen by the pathologist. Furthermore, centres that do not perform HIPEC procedures have to refer their patients after the primary resection, leaving a staged HIPEC procedure as the only option.

The obvious advantage of a simultaneous approach is that no secondary surgical procedure is required. Also, it is hypothesised that free intraperitoneal tumour cells become encapsulated with fibrin, which makes these cells less accessible for chemotherapy at a later stage. A hypothetical disadvantage of the staged procedure is the delay in adjuvant chemotherapy, which potentially increases the risk of distant metastases. Following the Dutch guidelines, adjuvant chemotherapy should be administered not later than 12 weeks after the primary resection, and most oncologists strongly prefer to start within eight weeks. However, the exact effect of delaying adjuvant systemic chemotherapy remains unclear, because most studies on this topic are subject to a selection bias. It is difficult to conclude whether worse oncological outcomes should be ascribed to the delay in chemotherapy or to the underlying cause of the delay (postoperative complications, worse patient condition and/ or comorbidities). The COLOPEC trial might provide the first comparative results that address the question of the effect of delayed adjuvant chemotherapy.

A second disadvantage of performing HIPEC several weeks after the resection of the primary tumour is the potential presence of intraabdominal adhesions that could cause difficulties in gaining access to the abdominal cavity and/or require adhesiolysis. However, both the present study and the published French study on staged adjuvant laparoscopic HIPEC revealed no conversions, even in patients who underwent open resection of the primary tumour [20], [32]. Adhesion scores are carefully registered during the staged HIPEC and the routine laparoscopy 18 months postoperatively to address this question in the COLOPEC trial.

Another option is second look surgery after six to twelve months, thereby not interfering with the standard resection and adjuvant systemic chemotherapy. However, disease progression might have occurred after six months, leading to the necessity of cytoreductive surgery in case of PMCRC. Results of the afore mentioned trials should be awaited to identify the most adequate approach, taking into account both the effectiveness and the extra morbidity of these preventive strategies.

In conclusion, pilot studies on adjuvant HIPEC in patients at high risk of developing PMCRC show promising results. These results have to be confirmed by currently recruiting randomized studies. Optimal patient selection and timing of prophylactic HIPEC are some of the issues that have to be resolved in the future.

\section{MATERIALS AND METHODS}

\section{Update of the pilot study on adjuvant staged laparoscopic HIPEC}

Between January 2011 and July 2012, ten patients were included in a single centre pilot study, with a diagnosis of adenocarcinoma of the colon and proximal rectum and at least one of the following risk factors for PMCRC: pT4, (resected) local peritoneal nodules in the close proximity of the primary tumour, primary tumour presenting with obstruction and/or perforation, positive cytology in peritoneal lavage, ovarian metastasis or omental metastasis [20]. More detailed in- and exclusion criteria have been published previously [20].

Included patients were planned to undergo a laparoscopic HIPEC procedure within 4 to 8 weeks after resection of the primary tumour. Perfusion with mitomycin-C $\left(35 \mathrm{mg} / \mathrm{m}^{2}\right)$ was performed for 90 minutes at a flow rate of $1-2 \mathrm{~L} / \mathrm{min}$ with an inflow temperature of $42-$ $43^{\circ} \mathrm{C}$. A detailed description of the laparoscopic HIPEC procedure can be found in the original report of the pilot study [20].

In the original pilot study, median length of followup of patients was 13 months (range 10-26). For the present analysis, data on long term oncological outcomes were collected retrospectively. All patients intentionally received follow-up according to the Dutch guidelines, with outpatient clinic visits every 6 months in the first two to three years and yearly thereafter, CEA measurements every 3 to 6 months in the first 2 years and every 6 to 12 months thereafter, and liver ultrasound or CT abdomen every 6 months in the first two years and yearly until 5 years after primary diagnosis.

For the original pilot study, approval was obtained from the Institutional Review Board at the Academic Medical Center, Amsterdam, the Netherlands. Patients consented to collection of anonymised long term data. Therefore, no separate ethical approval for the present study was obtained.

\section{Update of the systematic review of literature}

An update of our previously published systematic review of literature on intraperitoneal chemotherapy as 
adjuvant treatment to prevent PMCRC was performed [21]. The systematic search of published literature in Pubmed, Embase and the Cochrane database was repeated in November 2016 using the original search terms (Supplementary Figure 1).

Case series $(n \leq 5)$ were excluded, as well as nonEnglish language. For the purpose of the present update, eligibility of identified studies was restricted compared to the original review. Only studies describing the use of HIPEC in patients with CRC at high risk of developing PM were considered eligible for full text assessment. Furthermore, studies were included if primary data was provided on survival and/or peritoneal recurrence.

\section{Abbreviations}

CRC: colorectal cancer; CRS: cytoreductive surgery; DFS: disease free survival; FU: follow-up; HIPEC = hyperthermic intraperitoneal chemotherapy; PMCRC: peritoneal metastases of colorectal origin; pTN = pathological TN; OS: overall survival; PFS: progression free survival; R0: microscopic complete tumour resection with all margins $>1 \mathrm{~mm}$; R1: microscopic margin involvement or margin $\leq 1 \mathrm{~mm}$; $5 \mathrm{y}$ : 5 year.

\section{Author contributions}

Study conception and design: CK, JC, DS, WB, $\mathrm{CP}$ and PT. Data collection: $\mathrm{CK}$ and RS. Analysis and interpretation of data: CK, RS, JC and PT. Writing manuscript: CK, JC and PT. Revising it critically for important intellectual content RS, WB, DS, CP. All authors approved the final version of the manuscript.

\section{CONFLICTS OF INTEREST}

The authors have no conflicts of interest to declare.

\section{FUNDING}

There was no funding for this manuscript.

\section{REFERENCES}

1. Verwaal VJ, van Ruth S, de Bree E, van Sloothen GW, van Tinteren H, Boot H, Zoetmulder FA. Randomized trial of cytoreduction and hyperthermic intraperitoneal chemotherapy versus systemic chemotherapy and palliative surgery in patients with peritoneal carcinomatosis of colorectal cancer. J Clin Oncol. 2003; 21: 3737-3743.

2. Pelz JO, Chua TC, Esquivel J, Stojadinovic A, Doerfer J, Morris DL, Maeder U, Germer CT, Kerscher AG. Evaluation of best supportive care and systemic chemotherapy as treatment stratified according to the retrospective peritoneal surface disease severity score
(PSDSS) for peritoneal carcinomatosis of colorectal origin. BMC Cancer. 2010; 10:689.

3. Franko J, Shi Q, Goldman CD, Pockaj BA, Nelson GD, Goldberg RM, Pitot HC, Grothey A, Alberts SR, Sargent DJ. Treatment of colorectal peritoneal carcinomatosis with systemic chemotherapy: a pooled analysis of north central cancer treatment group phase III trials N9741 and N9841. J Clin Oncol. 2012; 30: 263-267.

4. Klaver YL, Lemmens VE, Nienhuijs SW, Luyer MD, de Hingh IH. Peritoneal carcinomatosis of colorectal origin: Incidence, prognosis and treatment options. World J Gastroenterol. 2012; 18: 5489-94.

5. Klaver YL, Lemmens VE, Creemers GJ, Rutten HJ, Nienhuijs SW, de Hingh IH. Population-based survival of patients with peritoneal carcinomatosis from colorectal origin in the era of increasing use of palliative chemotherapy. Ann Oncol. 2011; 22: 2250-2256.

6. Kok NF, de Hingh IH. Cytoreductive surgery and hyperthermic intraperitoneal chemotherapy for peritoneal metastases of colorectal origin. Br J Surg. 2017; 104;4:313-315.

7. Baratti D, Kusamura S, Pietrantonio F, Guaglio M, Niger M, Deraco M. Progress in treatments for colorectal cancer peritoneal metastases during the years 2010-2015. A systematic review. Crit Rev Oncol Hematol. 2016; 100: 209-222.

8. Razenberg LG, van Gestel YR, Lemmens VE, de Hingh IH, Creemers GJ. Bevacizumab in Addition to Palliative Chemotherapy for Patients With Peritoneal Carcinomatosis of Colorectal Origin: A Nationwide Population-Based Study. Clin Colorectal Cancer. 2016; 15:e41-6.

9. Maillet M, Glehen O, Lambert J, Goere D, Pocard M, Msika S, Passot G, Elias D, Eveno C, Sabaté JM, Lourenco N, André T, Gornet JM, BIG-RENAPE Working Group. Early Postoperative Chemotherapy After Complete Cytoreduction and Hyperthermic Intraperitoneal Chemotherapy for Isolated Peritoneal Carcinomatosis of Colon Cancer: A Multicenter Study. Ann Surg Oncol. 2016; 23:863-69.

10. Klaver CE, Musters GD, Bemelman WA, Punt CJ, Verwaal VJ, Dijkgraaf MG, Aalbers AG, van der Bilt JD, Boerma D, Bremers AJ, Burger JW, Buskens CJ, Evers P, et al. Adjuvant hyperthermic intraperitoneal chemotherapy (HIPEC) in patients with colon cancer at high risk of peritoneal carcinomatosis; the COLOPEC randomized multicentre trial. BMC Cancer. 2015; 15: 428.

11. Jayne DG, Fook S, Loi C, Seow-Choen F. Peritoneal carcinomatosis from colorectal cancer. Br J Surg. 2002; 89:1545-50.

12. Yang SH, Lin JK, Lai CR, Chen CC, Li AF, Liang WY, Jiang JK. Risk factors for peritoneal dissemination of colorectal cancer. J Surg Oncol. 2004; 87: 167-173.

13. van Gestel YR, Thomassen I, Lemmens VE, Pruijt JF, van Herk-Sukel MP, Rutten HJ, Creemers GJ, de Hingh IH. Metachronous peritoneal carcinomatosis after curative 
treatment of colorectal cancer. Eur J Surg Oncol. 2014; 40: 963-9.

14. Segelman J, Granath F, Holm T, Machado M, Mahteme $\mathrm{H}$, Martling A. Incidence, prevalence and risk factors for peritoneal carcinomatosis from colorectal cancer. Br J Surg. 2012; 99: 699-705.

15. Lemmens VE, Klaver YL, Verwaal VJ, Rutten HJ, Coebergh JW, de Hingh IH. Predictors and survival of synchronous peritoneal carcinomatosis of colorectal origin: a populationbased study. Int J Cancer. 2011; 128: 2717-2725.

16. Sugarbaker PH. Improving oncologic outcomes for colorectal cancer at high risk for local-regional recurrence with novel surgical techniques. Expert Rev Gastroenterol Hepatol. 2016; 10: 205-213.

17. Honoré C, Goéré D, Souadka A, Dumont F, Elias DC. Definition of patients presenting a high risk of developing peritoneal carcinomatosis after curative surgery for colorectal cancer: a systematic review. Ann Surg Oncol. 2013; 20: 183-192.

18. Pande R, Sunga A, Levea C, Wilding GE, Bshara W, Reid M, Fakih MG. Significance of signet-ring cells in patients with colorectal cancer. Dis Colon Rectum. 2008; 51: 50-5.

19. Noura S, Ohue M, Seki Y, Yano M, Ishikawa O, Kameyama M. Long-term prognostic value of conventional peritoneal lavage cytology in patients undergoing curative colorectal cancer resection. Dis Colon Rectum. 2009; 52:1312-20.

20. Sloothaak DA, Gardenbroek TJ, Crezee J, Bemelman WA, Punt CJ, Buskens CJ, Tanis PJ. Feasibility of adjuvant laparoscopic hyperthermic intraperitoneal chemotherapy in a short stay setting in patients with colorectal cancer at high risk of peritoneal carcinomatosis. Eur J Surg Oncol. 2014; 40: 1453-8.

21. Sloothaak DA, Mirck B, Punt CJ, Bemelman WA, van der Bilt JD, D'Hoore A, Tanis PJ. Intraperitoneal chemotherapy as adjuvant treatment to prevent peritoneal carcinomatosis of colorectal cancer origin: a systematic review. Br J Cancer. 2014; 111:1112-21.

22. Baratti D, Kusamura S, Iusco D, Gimondi S, Pietrantonio F, Milione M, Guaglio M, Bonomi S, Grassi A, Virzì $\mathrm{S}$, Leo E, Deraco M. Hyperthermic Intraperitoneal Chemotherapy (HIPEC) at the Time of Primary Curative Surgery in Patients with Colorectal Cancer at High Risk for Metachronous Peritoneal Metastases. Ann Surg Oncol. 2017; 24:167-75.

23. Sammartino P, Sibio S, Biacchi D, Cardi M, Accarpio F, Mingazzini P, Rosati MS, Cornali T, Di Giorgio A. Prevention of Peritoneal Metastases from Colon Cancer in High-Risk Patients: Preliminary Results of Surgery plus Prophylactic HIPEC. Gastroenterol Res Pract. 2012; 2012:141585.

24. Sammartino P, Sibio S, Biacchi D, Cardi M, Mingazzini P, Rosati MS, Cornali T, Sollazzo B, Atta JM, Di Giorgio
A. Long-term results after proactive management for locoregional control in patients with colonic cancer at high risk of peritoneal metastases. Int J Colorectal Dis. 2014; 29: 1081-1089.

25. Elias D, Goéré D, Di Pietrantonio D, Boige V, Malka D, Kohneh-Shahri N, Dromain C, Ducreux M. Results of systematic second-look surgery in patients at high risk of developing colorectal peritoneal carcinomatosis. Ann Surg. 2008; 247: 445-450.

26. Lee IK, Kim DH, Gorden DL, Lee YS, Sung NY, Park GS, Kim HJ, Kang WK, Park JK, Ahn CH, Kim JG, Jeon HM, Oh ST. Prognostic value of CEA and CA 19-9 tumor markers combined with cytology from peritoneal fluid in colorectal cancer. Ann Surg Oncol. 2009; 16: 861-870.

27. Gozalan U, Yasti AC, Yuksek YN, Reis E, Kama NA. Peritoneal cytology in colorectal cancer: incidence and prognostic value. Am J Surg. 2007; 193: 672-675.

28. Sugarbaker PH, Gianola FJ, Speyer JL, Wesley R, Barofsky I, Myers CE. Prospective randomized trial of intravenous $\mathrm{v}$ intraperitoneal 5-FU in patients with advanced primary colon or rectal cancer. Semin Oncol. 1985; 12:101-11.

29. Graf W, Westlin JE, Pahlman L, Glimelius B. Adjuvant intraperitoneal 5-fluorouracil and intravenous leucovorin after colorectal cancer surgery: a randomized phase II placebo-controlled study. Int J Colorectal Dis. 1994; 9:35-9.

30. Scheithauer W, Kornek GV, Marczell A, Karner J, Salem G, Greiner R, Burger D, Stöger F, Ritschel J, Kovats E, Vischer HM, Schneeweiss B, Depisch D. Combined intravenous and intraperitoneal chemotherapy with fluorouracil + leucovorin vs fluorouracil + levamisole for adjuvant therapy of resected colon carcinoma. Br J Cancer. 1998; 77: 1349-1354.

31. Vaillant JC, Nordlinger B, Deuffic S, Arnaud JP, Pelissier E, Favre JP, Jaeck D, Fourtanier G, Grandjean JP, Marre $\mathrm{P}$, Letoublon C. Adjuvant intraperitoneal 5-fluorouracil in high-risk colon cancer: A multicenter phase III trial. Ann Surg. 2000; 231:449-56.

32. Chouillard E, Ata T, De Jonghe B, Maggiori L, Helmy N, Coscas Y, Outin H. Staged laparoscopic adjuvant intraperitoneal chemohyperthermia after complete resection for locally advanced colorectal or gastric cancer: a preliminary experience. Surg Endosc. 2009; 23:363-9.

33. Tentes AA, Spiliotis ID, Korakianitis OS, Vaxevanidou A, Kyziridis D. Adjuvant perioperative intraperitoneal chemotherapy in locally advanced colorectal carcinoma: preliminary results. ISRN Surg. 2011; 2011:529876.

34. Lygidakis NJ, Patil A, Giannoulis K, Fukuda T, Kumar R. Laparoscopic hyperthermic intraperitoneal chemotherapy as adjuvant modality following radical surgery for advanced rectal cancer a new look to an old problem. Hepatogastroenterology. 2010; 57:73-75. 